\title{
Women in moral education and rising tide in social vices in Nigeria
}

\author{
Oteje, Kehinde M.J. ${ }^{1}$ \\ Email: otejek@yahoo.com \\ Egboh, Fasilat Bolaji ${ }^{2}$ \\ Email:Bolatate2014@gmail.com \\ Agranpe, Tanimowo Mautin ${ }^{3}$ \\ Email:mautintad@yahoo.com \\ Mafo, Akintoye Benjamin ${ }^{4}$ \\ Email: mafoakin_m1967@yahoo.com \\ ${ }^{1,2,3,4}$ Department of Educational Management, \\ Lagos State University, Ojo, Lagos State, Nigeria
}

\begin{abstract}
Women within the world play vital roles within the foundation of any kid. Right from conception, delivery and to adulthood, ladies devote love and her heart on the progress of the kid. Women had nice responsibilities within the upbringing of youngsters, particularly in moulding them to become nice men and girls.

Keywords: Nigeria, robberies, kidnappings, rape Chiekpaka.
\end{abstract}

\section{INTRODUCTION}

With youths daily changing into restless and concerned in numerous crimes way on the far side the comprehension of their oldsters, there's the requirement for girls to rethink their priorities reception and within the society that we have a tendency to sleep in. Odeh (2015) in his contribution declared that the speed at that immoral behaviour are practiced is overwhelming. Omede (2012) additional declared that the rise of ethical abjection within the Nigerian society makes it necessary for a re-examination at ways in which during which the correct values are often brought back to the society beginning with the youths. Youth restiveness has been on the rise within the country. In addition, Abraham (2011) declared that the negative image our youths have created within the space of gangdom and different vices have contributed to the unhealthy impression Federal Republic of Nigeria has been given among the committee of states. Several young boys and ladies are roaming concerning trying to find one crime or the opposite they'd commit. Majority of our youths are disobedient, disobedient, disrespectful and ever able to derail. Several of them are able to snatch, kill or wound folks so as to survive the onerous economy. Just about in each town in Federal Republic of Nigeria, social vices are daily being administrated by youths otherwise referred to as space boys. Omede (2012) additional thoroughbred that nobody must look way and wide to get the high rate of ethical abjection and staring show of wrong or negative values. the road urchins pull numerous crimes and lay beleaguering for unsuspecting victims. Painfully, several of those youths are lured into such behaviors because of the absence of their oldsters reception (women most especially). In support of this read, Misham (2007) perceived that the youths are pushed by the exploitatory and uncarpeted socio-economic system of the society.

Regrettably, these social vices have crept into colleges and not restricted to tertiary establishments. Each primary and school student is currently concerned. Then the requirement for women to trace back their responsibilities in kid upbringing is very important as a result of men don't have the ample time to grant adequate attention to youngsters as women will.

Most Nigerian youths have interaction in anti-social behaviour because of the family upbringing; some are from broken homes or defective homes which will seldom satisfy children's basic desires in addition to parental warm heartedness. The commonness of youth connected crimes, makes it nearly not possible for any parent to be therefore categorical on his or her ward particularly in Federal Republic of Nigeria wherever killings, armed robberies, kidnappings, rape and different crimes are being perpetrated on each day by the youths; a number of them from peer pressure however in totality, because of parental negligence.

Consequently, Njoku (2015) have supported that family instability could be a major explanation for ethical dissipation among Nigerian youths. as an example if oldsters fail in their responsibility to point out warm heartedness, steerage and correct discipline, the kids are probably to derail ethically; thus the requirement for moral education to be handled principally by ladies is incredibly essential so as to scale back the social vices effort our nation. 
Many argue that modern women are usurping male appointed responsibilities because of international depression which supplies them very little time for his or her ancient roles of taking care of the homes; others believe that women should still build efforts to make sure the correct upbringing of their youngsters. Women have tons to try and do to scale back the prevalence of crimes among the youths if they extremely keep in mind their ancient roles reception.

Women are playing their roles however most women are lacking. This is often as a result of their career women; who wake up early in the morning and return home in the night. They supply cash for gadgets however don't seem to be on the market for his or her youngsters. Some women are still playing however are lacking in their responsibilities towards citing the kids. This gave area to some youths concerned in yahoo and. Imagine associate degree eighteen years previous that desires to ride the simplest automotive as a result of he's into yahoo and. however will we have a tendency to get that concerned in organic process project? It goes back to background. Women have left their responsibilities to academics and caregivers. Women should close and appearance at what they'll do to assist the youths out.

Prevalence of social vices among youths is caused by women as they neglect their ancient roles as mothers; as a result of presently women additionally work to produce for his or her families. As a result, women don't seem to be doing enough of late in terms of impacting morals as a result of they're doing quite their ancient role of taking care of the homes and taking care of the kids. They're not acting their main duty however instead, serving to in monetary running of the house.

With current happenings within the society, and in an exceedingly state of affairs wherever wealthiness is being flaunted by the political category and nuance by the elite category, the result's attendant social vices among that is that the get made syndrome. Also, ethics and family values area unit step by step being worn within the society. Several women don't pay time with their youngsters not to mention impact ethical directions. This was in support of Saheed (2013) read that expressed that low ethical commonplace and hypocrisy of the elder generation provides space for the youths to urge themselves concerned in ethical degeneracy once youths determine that the older generation is somewhat insincere, in this they fake to instill set of ethical norms however smartly pursues the opposites. As a result, they have an inclination to affix within the camouflage means of life.

Idleness is an element of what's inflicting prevalence of social vices and women don't seem to be around to curb peer pressure. In line with Chiekpaka (2012), youth restiveness ends up in breakdown of law and order, economic misfortune because of disruption of economic activities, redoubled rate, intra-ethnic hostilities, harassment of prospective developers and different sundry criminal tendencies. Rather like the bible says in Proverbs 22:6 "Train up a baby within the means he ought to go and once he's recent, he won't depart from it." It so places on the women the final word right and responsibility for raising higher youngsters, therefore, creating up a healthier society.

\section{MORAL EDUCATION}

Moral education is a problem that's presently being wide mentioned as a result of the ethical degeneracy of youths. The Nigerian society notably is currently in serious crisis for the high level of immorality that prevails in our society. Nowadays such a lot of adolescent and adult's area unit delinquent and divided in character. Moral education so isn't simply to cushion the black effects of the social evils however additionally to cut back the incidence of delinquency and deviancy.

Education is simply complete once it ends up in all spherical development of the individual, that encompasses not solely mental however additionally ethical development. During this wise, in line with John (2005), education could be a data giver which supplies knowledge and a more robust understanding of ourselves et al. to keep up peace living. That is, one's life has worth farewell in concert attributes worth to the lifetime of others, by means that of affection, friendship, outrage and compassion. Moral education so influences the social thinking of the individual and makes him/her distinguish between what's right and what's wrong. Moral education could be a basic would like for contemporary times wherever one is quick witnessing a degeneration of ethical values. Moral education is vital because it teaches diversity, tolerance, mutual respect and school of thought values. It's so not simply to cushion the black effects of the social evils however additionally to cut back the incidence of delinquency and deviancy.

The word ethical comes from a Latin root (mos, moris) and means that the code or customs of land, the social glue that defines however people ought to live along.

Moral values area unit values that specific concepts regarding the nice life. As such, concern for the ethical virtues, like honesty, responsibility, and respect for others, is that the domain of ethical education. Since ills area unit principally perpetrated by the youths underneath the semblance of socialization and 
acquisition of technological power that Olusanya (2013) ruminates as requisite for the understanding of the principles of economic process, if they are doing not have correct steering, it's necessary that society provides them with a kind of education which will build them acquire sound spiritual and ethical principles, and additionally develop applicable attitudes and values which will facilitate them to create smart selections and selections in their adulthood.

Moral education, then, refers to serving to youngsters acquire those virtues or ethical habits which will facilitate them severally live smart lives and at identical time become productive, contributory members of their communities.

In this read, Moral education ought to contribute not solely to the scholars as people, however additionally to the social cohesion of a community. an ethical education system should begin by process the morals that area unit most significant for not solely the individual except for the society as a full.

The system should be designed intrinsically that the individual at a formative stage ought to distinguish to differentiate between what's smart and what's dangerous. Here sensible learning ought to take precedence over studious learning. The atmosphere during which individuals live has continually influenced patterns of behaviour, attitudes, actions, beliefs, values and ethics. Consequently, Rogers (2003) viewed ethical drunken revelry as non-compliance through their parental upbringing, peer or social group influence.

Elegbeleye (2005) disclosed that children everywhere the planet square measure a significant and important section of the society within which they live. A disciplined, focused, and law-abiding youth will produce a bright future for any nation. On the opposite hand, a lawless, indulgent, and violent youth could be a nice threat to a nation's peace and security. Hence, moral education if adequately handled by our women from home can equip youths with tools of judgments in varied things resulting in creating accountable selections and selections. Therefore, moral education ought to be associate degree integral a part of home teaching by mothers to scale back the social vices within the society.

Agreeing with National Youth Development Policy (2001) "Youth are the foundation and the inspiration of a society. Their energies, cleverness, character and orientation outline the pace of development and security of a nation. Through their inventive skills and labour power, a nation makes big strides in economic development and socio-political attainments. In their dreams and hopes, a nation founds her motivation; on their energies, she builds her vitality and purpose. And since of their dreams and aspirations, the longer term of a nation is assured. (p.1). In support of the on top of read, Ozohu-Sulaiman (2006) acknowledges the role of the youth within the peace and security of a nation. She maintained that because the most active section of any society, youth square measure the key determinants of peace and stability of a nation conversely, the degree of disorderliness and instability in any society is additionally determined to a good extent by the youth of such society. Thus home moral education is that the answer to the decrease of social vices within the society. The National Youth Policy (2001) once additional to state that the extent of the youth's "responsible conduct and roles in society is absolutely related to with the event of their country", (p.1). Peace could be a precursor of development. The absence of peace implies that no important development will come about.

\section{The Importance of Moral Education}

Moral education is essentially a coaching that shows United States of America the proper and simply thanks to lead our lives. Being honest, just, legitimate, accommodative, generous, to share love and care; show thought and sensitivity square measure basic principles of ethical education. It's a lot of a follow that enriches the method of our life-style. Moral education is rendered reception, school, by tutors, elders and oldsters. It's best educated by active what's right and simply before of the child. It associate degree education for all and may be done at every and each time. It's not restricted by geographical boundaries and skillful trainers. It's best educated by shown sensible examples.

Every young parent ought to be terribly attentive toward their children's demand of ethical education. Childhood is that the most vulnerable amount that impacts the general development of associate degree individual's temperament. As a parent be attentive concerning what your child is learning and from wherever. As a women, you would like to use caution concerning the peer and friends your kid may need and take outing to create them perceive what's right and wrong.

Children square measure the inspiration of our society the torchbearers of our nation. Women as a lecturer associate degreed an influencer should look out of the ethical coaching and basic qualities that square measure presented on the kids. It'll eventually have an effect on the fate of the country as a full.

Every time a toddler is caught lying or gets out of hand, necessary substance needs to lean to them. It's 
necessary to treat them as associate degree equal and show trust and religion in them and build them assured to require their own calls. They must perpetually be educated that it'd be tough, to inform the reality, however it's perpetually essential to inform the reality. Stories and examples should be shared with them in order that they need a lot of clarity of thought. Offer them time and treat them patiently in any respect times.

It is additionally necessary to teach youngsters to be disciplined and to not cheat whereas at school and examinations. they're to be educated that there are no not associate degree shortcuts in life and life is an examination wherever there's no information, the sole issue which will get them to' could be a sensible character and speaking the reality in any respect times.

It is necessary to teach youngsters concerning the outstanding activists and legends that exemplifies strength and has shown character to fight against all odds and champion the proper causes to bring revolutionary changes. These reformers and prophets ought to be the role models that the youth ought to follow and appearance up to. Assist your youngsters to seek out a cause price operating for, build them contribute to voluntary services and serving to the poverty-stricken. After they begin these as a habit from childhood, they will take it forward in their lives. Every kid will build a big contribution in their own method.

It is additionally necessary to inform your youngsters the severity of the social control one may get committing crimes and heavy offenses. They need to be clear on what's right and wrong. Be a mentor than a parent and check with your kid as a lover, it'd be a drum sander method for them to find out. Share your past mistakes, its consequences and what you learned from it. don't discourage their venturesome spirit however teach them to balance it between associate degree journey and a misfortune. Additionally, Agbaje (2012) Affirmed that youths don't seem to be solely leaders of tomorrow, however partners of nowadays. As a matter of reality a nation's future is foretold supported the standard of its youths. In agreement to Agbaje statement, Kumar (2008) declared that if the youths lose their method or direction, it'd become terribly serious and horrible for a Nation. Hence, ladies should get up to their responsibilities for kid upbringing.

\section{CONCLUSION}

The high rate of negative social vices lately is attributed to women negligence to their responsibilities as regards ethical teachings reception. A baby being a product of a family so represents the values, morals and ethics of that family. The extent of development a baby manifests in later life reflects to the kind of home background, experiences, exposure and coaching, a baby gets in early years. Train up a baby within the method he ought to go and once he's recent, he won't depart from it."- Proverbs 22:6. This passage within the Holy Book, the Bible, is arguably the foremost recommendable for children's upbringing. It so places on the ladies the last word right and responsibility for raising higher kids, therefore, creating up a healthier society.

\section{RECOMMENDATION}

1. On cutting occurrence of social vices among the youths, we have a tendency to return to ethical home training.

2. Women ought to teach their wards on the negative effects of social vices.

3. They must teach the youth's ethical values at each level.

4. Women ought to devote longer in observation, correction and ingraining discipline on kids reception.

\section{REFERENCES}

[1] Agbaje, I, (2012). Towards Achievement of Sustainable Development through Technical and Vocational Education and Training (TVET): A case of Middle Level Colleges- Kenya. Journal of Emerging Trends in Educational Research and Policy Studies, 3(5), 686 - 690

[2] Chiapaka, I. J. (2012). "Towards curbing youth restiveness", in Nigerian Tide, (p.2). 20th August

[3] Elegbeleye, O. S. (2005). Recreational facilities in schools: A panacea for youths' restiveness. Journal of Human Ecology 18 (2): 9398.

[4] Federal Government of Nigeria, (2001). National Youth Policy; http://www.thepresidency.gov.za/docs/policy/nationalyouthpolicy.pdf.

[5] John, I. (2005). Diversity and inclusion: Towards a curriculum for humanbeings. Teachers College Record, 95(2) 211-221.

[6] Kumar, L (2008). Sustainable Agriculture Production: Implications for International Agricultural Research. FAO Research and technology paper 4. Rome, Italy

[7] Misham S. V. (2007). Moral decadence among the student. Abuja: Ventures Books Ltd.

[8] Njoku N. C. (2015). Repositioning Nigeria Youths through the teaching of moral institution in the 21st century. British Journal of Education, 3(7) 9-17.

[9] Odeh, J.C. (2015). Moral decadence among catholic youths in Abakaliki diocese. Unpublished Thesis of Ebonyi State University, Abakaliki.

[10] Olusanya, J. O. (2013). Towards national security and transformation: Vocational and technical Volume 3, Issue IX, September 2020|4 
education option. Keynote address presented at the 11th National Conference on Vocational and Technical Education, Abeokuta, 2nd July.

[11] Omede, B (2012) Revised Recommendation Concerning Technical and Vocational Education. In Normative Instruments concerning technical and vocational education. Online: http://www.unevoc.unesco.org/go.php?q=UNEVOC+publicatins\&lang=en\&akt=i\&st= $\& q s=70 \&$ unevoc $=$ i. Retrieved 20/02/2012 UNESCO (2005). Learning for Work, C

[12] Ozohu-Suleiman, A. (2006) "The Nigerian youth in contemporary political development: Relevance, challenges and role expectation", in the constitution: A journal of constitutional development (p. 97-111) vol. 6(4).

[13] Rogas P. S. (2003). Moral Development and Moral education. London: Allen \& Union.

[14] Saheed, I.T. (2013). Moral decadence, causes, effects and solution. Journal of Education and Management Sciences, 2(4), 122-144.

[15] Irgashevich, D. A. (2020). Development of national network (tas-ix). ACADEMICIA: An International Multidisciplinary Research Journal, 10(5), 144-151. Article http://dx.doi.org/10.5958/2249-7137.2020.00254.2 